\title{
PENDEKATAN SUFISTIK DALAM MENAFSIRKAN
}

\author{
AL-QURAN
}

\author{
Badruzzaman M. Yunus
}

UIN Sunan Gunung Djati Bandung

\begin{abstract}
ABSTRAK
Karya-karya tafsir Alqur'ân bercorak sufistik seperti halnya tasawuf sebagai disiplin ilmu, mendapat label plus-minus dari para pengkaji. Imam al-Thusiy mengomentari penafsiran sufi sebagai "Penafsiran seperti itu keliru (خطاء) dan dusta (بهتان) kepada Allâh”. Imam al-Suyuthiy menyatakan bahwa pendapat para sufi dalam memaknai Alqur'ân tidak dianggap sebagai tafsir. Ibn Shalah dalam Fatâwa-nya, Ia mengutip apa yang dikatakan oleh Imam Abi Hasan al-Wahidi; siapa yang menganggap bahwa kitab al-Sulami itu kitab tafsir maka ia telah menjadi kafir. Demikian juga penolakan dari Imam al-Zarkasyiy, Imam al-Nasafi dan Imam al-Rafi'iy. Sementara itu, banyak ulama yang memandang bahwa tafsir sufistik memiliki faidah untuk mengurai sisi esoterik Alquran dengan asumsi bahwa Alqur'ân memiliki makna dzahir dan makna bathin. Jika demikian, maka tafsir sufistik memiliki kontribusi jelas pada pemaknaan dari aspek bathinnya dengan perangkat takwil atau isyarat-isyarat tertentu, sementara untuk makna dzâhir-nya sudah digarap oleh perangkat tafsir. Imam al-Ghazali menegaskan bahwa tidak ada larangan seseorang menafsirkan Alqur'ân dengan penafsiran sufistik jika bermaksud untuk menampilkan kekayaan makna Alqur'ân hingga batas-batas pemaknaan dengan simbol atau isyaratisyarat tertentu. Perdebatan tentang status tafsir sufistik antara kebolehan membaca, memahami dan mengamalkannya seperti yang representasikan oleh Imam al-Ghazali versus beberapa ulama yang menolak karya-karya tafsir sufistik, me-niscayakan untuk mendefinisikan tafsir sufistik dan me-metakan (mapping) tafsir sufistik dengan membuat kategori-kategori baik paradigma, karya-karya, kelebihan-kelebihan dan kekurangan-kekurangannya. Teori tafsir sufistik merujuk pada karakteristik metodologi tafsir Alqur'ân yang terbagi kedalam tiga bagian bersar; referensi tafsir (mashadir); referensi tafsir informatif (matsur), nalar (ma'qul) dan intuitif/esoterik (isyariy), metode tafsir (manhaj); ijmaliy, tahliliy, muqaran dan mawdluiy dan yang terakhir adalah teori tentang pendekatan/corak tafsir. Penelitian ini menemukan bahwa secara paradigmatik, posisi tafsir sufi mengambil ruang esoterik dengan memakai perangkat takwil. Tafsir sufistik terbagi kepada dua kategori; isyariy; tafsir yang diperoleh dari isyarat-isyarat ghaib dan nadzariy; penafsiran dengan teori-teori tasawuf dan filsafat (theosophy, tasawuf-falsafi). Pendekatan tafsir sufi berupaya memaknai Alquran dengan menggunakan tasawuf sebagai ilmu bantu. Tafsir dengan corak sufistik memiliki kelebihan terutama pada penyingkapan makna esoterik, bathin Alquran, sementara kelemahannya adalah tidak ada tolok ukur validitas dan hanya dikonsumsi oleh komunitas terbatas.
\end{abstract}

KATA KUNCI

Sufiy; Isyariy; Nadzâriy; Pendekatan Tafsir; Corak Tafsir

DOI: https://doi.org/10.15575/saq.v2i1.2384

\section{A. PENDAHULUAN}

Banyak penjelasan dan ulasan yang dinisbahkan kepada disiplin ilmu tasawuf; dari mulai penjelasan yang mengusung keniscayaan ilmu ini untuk dipelajari, mesti dikembangkan dan dipraktekkan dalam kehidupan keseharian. Dalam konteks ini, ilmu tasawuf memiliki kontribusi yang sangat besar dalam upaya memperbaiki akhlak (tasawuf akhlaqi), melatih hati dan menelusuri kehadiran Khaliq (thariqat), 
berupaya mengenali ( $m a$ 'rifat) dan berupaya menghilangkan sekat-sekat antara dirinya dan sang Khaliq ,"menyatu", "melebur" denganNya (haqiqat). Di sisi lain, ada yang menganggap tasawuf sebagai disiplin ilmu yang ambigu, tidak jelas, bid'ah karena tidak dicontohkan oleh Rasulullah Muhammad saw., aktivitas kaum zindiq, tidak rasional, berlebihan, tidak dapat diukur dengan paradigma rasional-empirik dan seterusnya. Tradisi sufistik dianggap sebagai keyakinan yang disertai dengan praktek ibadah yang penuh dengan khurafat dan takhayul, termasuk upaya memaknai Alquran yang dilakukan oleh oleh orang-orang sufi atau tafsir yang bercorak sufi ${ }^{1}$.

Realitasnya, disiplin ilmu ini terus berkembang dan dalam rentang sejarah dari mulai zaman klasik, pertengahan, modern hingga kontemporer, banyak bermunculan tokoh-tokoh tasawuf disertai dengan gagasan-gagasan sufistik mereka yang dicurahkan dalam karya-karya mereka. Tetap exist-nya lembaga-lembaga thariqat [tasawuf yang dilembagakan] sepanjang sejarah hingga zaman kontemporer mengisyaratkan bahwa tasawuf bagi sebagian orang tetap dianggap sebagai pilihan yang dianggap meyakinkan.

Karya-karya tafsir Alquran bercorak sufistik seperti halnya tasawuf sebagai disiplin ilmu, mendapat label plus-minus dari para pengkaji. Imam al-Thusiy mengomentari penafsiran sufi ketika menafsirkan totalitas Alquran dari al-Fatihah hingga surat al-Nas. Basmalah di surat alFatihah. "Kalimat لبسم الله الرحمن الرحيم diawali

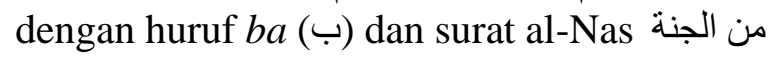
diakhiri dengan huruf sin (س). Kedua huruf itu jika digabungkan menjadi بَس (bas) yang berarti cukup. Kata ini mengandung

${ }^{1}$ Asimain, al-Fikr al-Shufiy fi Dlau al-Quran wa al-Sunnah, Ibn Shalah, Fatawa Ibn Shalah: 232-233

2 Abd al-Rahman al-'Ak, Ushul al-Tafsir wa Qawa'iduhu, 1986. Dar al-Nafais Damaskus Syiria cet. Ke III, 215.

3 Abd al-Rahman al-'Ak, Ushul al-Tafsir wa Qawa'iduhu, , 215. Dikutip oleh Abd al-Rahman al- makna bahwa Alquran ini sangat lengkap dan tidak perlu untuk mendapatkan informasi dari yang lain". Al-Thusiy mengatakan bahwa: "Penafsiran seperti itu keliru (خطاء) dan dusta (بهنان) kepada Allah". Menurutnya, ini adalah bentuk penyimpangan dalam tafsir. ${ }^{2}$ Imam al-Suyuthiy menyatakan bahwa pendapat para sufi dalam memaknai Alquran tidak dianggap sebagai tafsir. ${ }^{3}$ Ibn Shalah dalam Fatawa-nya, Ia mengutip apa yang dikatakan oleh Imam Abi Hasan al-Wahidi; "al-Sulami telah menyusun kitab dengan judul Haqaiq al-Tafsir. Barangsiapa yang menganggap bahwa kitab itu adalah kitab tafsir maka sungguh ia dianggap telah menjadi kafir" 4 . Imam al-Taftazaniy dan Ibn 'Atha menolak keras penafsiran kaum sufi' Demikian juga penolakan yang dikemukakan oleh Imam al-Zarkasyiy, Imam al-Nasafi dan Imam al-Rafi'iy. Penolakan-penolakan dari para ulama cukup banyak terhadap tafsir sufistik.

Sementara itu, banyak ulama yang memandang bahwa tafsir sufistik memiliki faidah untuk mengurai sisi esoterik Alquran dengan anggapan bahwa Alquran memiliki makna dzahir dan makna bathin. Jika demikian, maka tafsir sufistik memiliki kontribusi jelas pada pemaknaan dari aspek bathinnya dengan perangkat takwil atau isyarat-isyarat tertentu, sementara untuk makna dzahirnya sudah digarap oleh perangkat tafsir.

Imam al-Ghazali menegaskan bahwa tidak ada larangan seseorang menafsirkan Alquran dengan penafsiran sufistik jika bermaksud untuk menapilkan kekayaan makna Alquran hingga batas-batas pemaknaan dengan simbol atau isyarat-isyarat tertentu. AlGhazali mencontohkan penafsiran "fakhla" na'laika (فاخلع نعليك ) dengan penafsiran;

\footnotetext{
'Ak dari kitab al-Itqan fi 'Ulum Alquran dengan redaksi: وأما كلام الصوفية فى القران فليس بتفسير.A .

4 Abd al-Rahman al-'Ak, Ushul al-Tafsir wa

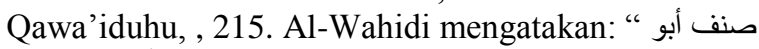
عبد الرحمن السلمى (حقائق التفسير) فإن كان قد اعتقد أن ذلك تفسير فقد كفر"

5 Abd al-Rahman al-'Ak, Ushul al-Tafsir wa
} Qawa'iduhu, , 215 
"barangsiapa yang ingin menemukan hakikat ke_maha Tunggalan Allah maka harus melepaskan pemikiran tentang dunia dan akhirat. Artinya mesti menerima Allah tanpa syarat dan yang difikirkan hanya "ridla Allah" dan "mencintai-Nya". 6 Selanjutnya al-Ghazali mengingatkan; "jangan mengira bahwa contoh yang saya sebutkan pada pemaknaan esoterik ayat di atas sekaligus menegasikan makna dzahirnya. Karena mengasikan makna dzahir adalah perbuatan orang-orang aliran bathiniyyah, tetapi juga, orang yang memaknai Alquran hanya dengan makna dzahirnya adalah rancu (حشوي).7

Perdebatan tentang status tafsir sufistik antara kebolehan membaca, memahami dan mengamalkannya seperti yang representasikan oleh Imam al-Ghazali versus beberapa ulama yang menolak karya-karya tafsir sufistik, me-niscayakan untuk mendefinisikan tafsir sufistik dan me-metakan (mapping) tafsir sufistik dengan membuat kategori-kategori baik paradigma, karya-karya, kelebihan-kelebihan dan kekurangan-kekurangannya. Sehingga tidak terkonsentrasi pada justifikasi atau penghakiman boleh tidak boleh tetapi beralih pada apa, bagaimana dnn signifikansi dari tafsir sufistik.

\section{B. TERMA TASAWUF PRAKSIS التصوف DAN TEORITIS (التصوف العملى)

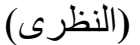

Sebelum masuk pada diversifikasi antara tasawuf praksis dan teoritis, terlebih dahulu mesti difahami dulu batasan tasawuf yang dikemukakan oleh para tokoh yang berkecimpung di dalamnya dan definisi yang diambil dari para pengkaji tasawuf. Syekh Junaidi al-Baghdadiy seorang tokoh tasawuf memberikan definisi tasawuf sebagai; disiplin ilmu yang di dalamnya berisi tentang sepuluh inti ajaran. Pertama; menyedikitkan

6 Abd al-Rahman al-'Ak, Ushul al-Tafsir wa Qawa'iduhu, , 214.

7 Abd al-Rahman al-'Ak, Ushul al-Tafsir wa Qawa'iduhu, , 214 benda-benda duniawi (materil) dan tidak memperbanyaknya/ menumpuk-numpuknya [al-qana'ah wa al-juhud]. Dua; melakukan penyerahan diri kepada Allah secara total [tawakkal]. Tiga; cinta kepada ketaatan dengan mengerjakan segala hal yang disunnahkan [al-hubb li al-'amal]. Empat; bersikap sabar dari kehilangan dunyawiyah dengan tidak berkeluh kesah dan tidak meminta-minta [al-shabr]. Lima; memilihmilih sesuatu ketika hendak mengambil atau mengerjakannya [ikhtiyariy]. Enam; Hanya menyiibukan diri dengan Allah daripada urusan-urusan yang lain. Tujuh; banyak mengingat Allah [al-dzikr]. Delapan; bersikap ikhlas dalam segala aktivitas (amalan) hanya karena Allah semata [alikhlash fi kuli 'amal]. Sembilan; keyakinan yang kuat [al-yaqin]. Sepuluh; bersikap tenang bersama Allah ketika muncul rasa gelisah dan dalam situasi keterasingan ${ }^{8}$.

Selanjutnya definisi diungkapkan oleh Abu Nu'man, Ia menyebutkan seputar definisi atau pengertian sufi dan tasawuf dengan narasi sebagai berikut: Abu al-Hasan al-Farghani berkata: Saya bertanya kepada Abu Bakr asy-Syibli: "Siapakah menurut anda seorang yang disebut sufi itu?", Abu alHasan al-Farghani menjawab: "Dia adalah seorang yang mengikuti ajaran Rasulullah, menyimpan dunia di balik punggungnya, dan menundukkan hawa nafsunya dengan kepayahan-kepayahan". Aku bertanya lagi kepadanya: "Ini adalah definisi sufi, lantas apakah yang disebut dengan tasawuf menurut anda?" Abu al-Hasan al-Farghani menjawab: "Tasawuf adalah upaya memurnikan hati (khalish) hanya bagi Allah Yang Mengetahui segala hal yang gaib". Aku bertanya lagi: "Yang lebih tinggi dari itu, apa definisi tasawuf?" Abu al-Hasan al-Farghani: "Menjalankan segala perintah Allah dan bersikap lemah lembut kepada setiap hamba Allah". Selanjutnya aku bertanya lagi:

\footnotetext{
${ }^{8}$ Al-Qusyairiy, al-Risalah al-Qusyairiyyah , h: 27-
} 
"Lebih tinggi lagi levelnya dari definisi yang tadi, siapakah seorang sufi itu?" Abu alHasan al-Farghani: "Sufi itu adalah seorang yang menjauhkan dirinya dari segala kekeruhan, berupaya mensucikan dirinya dari segala kotoran, memenuhi hatinya dengan mengingat Allah, dan tidak ada perbedaan baginya antara emas dan butiran debu'.

Tasawuf pada mulanya merupakan amalan-amalan dan pengalaman-pengalaman seseorang atau komunitas tertentu yang bersifat pribadi (personal experiences). Aktivitas ini lebih merupakan "rasa" dan "temuan". Ketika melakukan ibadah seperti kenyamanan dalam dzikir dengan jumlah tertentu dan dengan cara tertentu ${ }^{10}$ misalnya, ber-khlwat di tempat yang dianggap nyaman dengan durasi waktu tertentu, wirid dengan membaca kalimah, ayat-ayat, surat-surat alQuran, rasa penyatuan diri dengan sang Khaliq atau melihat seberkas cahaya yang sangat terang dalam hadir atau mimpi misalnya dan seterusnya. pengalamanpengalaman seseorang dalam menjalankan ibadah tersebut kemudian diungkapkan kepada khalayak. Pengungkapan pengalaman personal kepada khalayak bisa menjadi bias, karena informasi yang disampaikan tidak akan sama persis dengan apa yang dialami. Proses transformasi dari pengalaman ke teori akan tereduksi oleh keterbatasan kata yang tidak selalu mewakili realitas yang dialami. Karenanya, tasawuf ketika di-teori-kan terkadang tidak selalu mewakili aktivitas sufistik pada tataran praksis [amaliy].

\footnotetext{
9 Abu Nu'aim, Hilyah al-Auliyâ' dengan sanad bersambung hingga al-Junaid, j. 1, h.22

10 Kasus bervariasinya jumlah dzikir dan cara melakukan dzikir pada awalnya mungkin lebih pada pengalaman seseorang ketika berdzikir, merasa nyaman atau merasa cukup dengan jumlah dan cara tertentu. Misalnya, ritus dzikir di thariqat Qdiriyyah berjumlah 66 dan di thariqat QadiriyyahNaqsabandiyyah berjumlah 165. Selanjutnya, jumlah ini dianggap dosis yang kemudian dicari rasionalisasinya. Rasionalisasi yang penulis maksudkan adalah penjelasan logis kenapa jumlah dan caranya sekian. Merujuk kepada beberapa literatur ilmu "Hikmah" seperti kitab Abu Ma'syar al-Falakiy,
}

Dengan demikian, terma tasawuf teoritis (nadzariy) sesungguhnya adalah teorisasi dari pengalaman-pengalaman kaum sufi baik personal maupun kolektif. Pengalamanpengalaman kaum sufi ini yang kemudian disebut dengan tasawuf praksis [amaliy]. Penyataan Ibn Arabi dengan menyebut definisi operasional tasawuf menjadi sepuluh adalah skriptualisasi dari amalan keseharian kaum sufi.

\section{TAFSIR SUFISTIK}

Berbicara tafsir sufistik wujud kongkritnya berarti berbicara tentang karyakarya tafsir yang telah dibuat oleh para tokoh tasawuf baik yang dikategorikan sebagai tafsir sufi isyari maupun tafsir sufi nadzari. Kajian tafsir sufistik berarti melakukan pembacaan terhadap karya-karya tafsir bercorak tasawuf baik kajian metodologis maupun content (tema-tema tertafsir). Disamping itu, kajian awal tafsir sufistik juga mengkaji definisi, setting sosio-historis munculnya karya-karya tafsir sufistik, kelebihan dan kekurangan tafsir dengan corak ini serta langkah-langkah teknis upaya mendekati al-Quran dengan menggunakan disiplin ilmu tasawuf (sufistic approach to the Quran).

\section{Pengertian Tafsir Sufistik}

Syams al-Ma'arif, Manba' al-Hikmah dan seterusnya, alfabet/ abjad arab sering digunakan untuk "menghitung" karakter-karakter atau upaya menemukan petunjuk. Dalam konteks dzikir, kalimat اله terdiri dari alif= 1+ lam=30+lam=30+ ha=5 (66). Thariqat Qadiriyyah jumlah dzikirnya 66 karena yang disebutkan dalam dzikir hanya kata أله . sementara

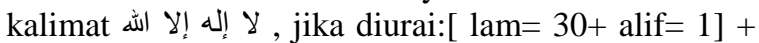
$[$ alif $=1+$ lam $=30+$ ha $=5]+[$ alif $=1+$ lam $=30+$ alif $=1]+[$ lafadz Allah 66 $]=165$. Thariqat Qadiriyyah-Naqsabandiyyah melafalkan dzikirnya dengan kalimat لا إله إلا اله dan setelah dihitung jumlah huruf-hurufnya sebanyak 165 . 
Pengertian tafsir sufi banyak dikemukakan oleh para ulama baik ulama salaf (klasik) maupun ulama khalaf (modernkontemporer). Imam Muhammad Ali alShabuni mendefinisikan tafsir sufistik sebagai berikut:

Penafsiran isyariy ditandai dengan adanya perbedaan dengan makna dzahir ayat karena adanya petunjuk-petunjuk (dilalah) yang tersirat dan hanya diketahui oleh sebagian ulama tertentu, atau hanya diketahui oleh orang yang mengenal Allah (ma'rifat) yaitu orang yang berkahlak tinggi dan telah terlatih jiwanya (mujahadah)" orang-orang yang telah diberi cahaya oleh Allah SWT. sehingga mampu menjangkau rahasiarahasia yang terkandung dalam alQur'an, akalnya penuh dengan pemahaman yang mendalam dengan jalan ilham, atau pertolongan dari Allah, sehingga mereka mampu menggabungkan antara pengertian yang tersirat (dzawahir) dengan maksud yang tersurat (isyarat) dari ayat al-Qur'an ${ }^{11}$

Dalam beberapa literatur, pembagian tafsir sufi terbagi ke dalam dua bagian; nadzariy dan isyariy. Para ulama membuat dua bagian seperti itu untuk mengkontraskan antara keduanya (versus). Mayoritas ulama salaf menolak tafsir yang masuk kategori tafsir sufi nadzariy dan membolehkan tafsir sufi isyariy.

Tafsir sufi nadhari adalah tafsir sufi yang dibangun untuk mengusung dan memperkuat teori-teori mistik yang dianut mufassir. Muhammad Husen al-Dzahabi mengatakan bahwa tafsir sufi nadhari pada prakteknya adalah penafsiran yang tidak memeperhatikan aspek bahasa dan menegasikan apa dikehendaki oleh syara.

Ulama yang dianggap representatif dalam tafsir tasawuf teoritis (nadhari) yaitu Muhyiddin Ibn al-'Arabi. Ibn 'Arabi dianggap sebagai ulama tafsir sufi nadhari

11 Muhammad Ali al-Shabuni, Rawa'i al-Bayan, 1999: 134

${ }^{12}$ Husen al-Dzahabi, al-Tafsir wa al-Mufassirun yang meyandarkan bebarapa teori-teori tasawufnya dengan al-Qur'an. Karya tafsir Ibn al-'Arabi di antaranya al-Futuhat alMakiyah.

Muhammad Husen al-Dzahabi menjelaskan karekteristik atau ciri-ciri dalam penafsiran nadhari sebagai berikut : Pertama, dalam menafsiran ayat-ayat alQur'an, tafsir sufi nadhari sangat kuat dipengaruhi oleh disiplin ilmu filsafat. Kedua, di dalam tafsir sufi nadhari, hal-hal yang bersifat gaib ditarik ke dalam sesuatu yang nyata atau tampak (profan) dengan perkataan lain meng-analogikan yang gaib pada yang nyata. Ketiga, terkadang mengabaikanstruktur gramatika bahasa Arab dan hanya menafsirkan apa yang sejalan dengan keinginan penafsir ${ }^{12}$.

Pembagian berikutnya adalah tafsir sufi isyari yang didefinisikan dengan: "Pentakwilan ayat-ayat al-Qur'an yang berbeda dengan makna lahirnya sesuai dengan petunjuk khusus yang diterima para tokoh sufisme tetapi di antara kedua makna tersebut dapat dikompromikan". ${ }^{13}$

Metode yang dipakai dalam tafsir tasawuf secara umum adalah metode isyarat (Isyarah). Isyarat di sini maksudnya adalah menyingkap apa yang ada di dalam makna lahir suatu ayat untuk mengetahui hikmahhikmahnya.

Az-Zahabi memeberikan penjelasan mengenai perbedaan antara tafsir sufi nadzari dengan tafsir sufi isyari sebagai berikut :

Tafsir sufi nadzari dibangun atas dasar pengetahuan ilmu sebelumnya yang ada dalam seorang sufi yang kemudian menafsirkan al-Qur'an yang dijadikan sebagai landasan tasawufnya. Adapun tafsir sufi isyari bukan didasarkan pada adanya pengetahuan ilmu sebelumnya, tetapi didasari oleh ketulusan hati seorang sufi yang mencapai derajat tertentu sehingga tersingkapnya isyarat-isyarat al-Qur'an.

13 Abd al-Rahman al-'Ak, Ushul al-Tafsir wa Qawa'iduhu, , 205 
Dalam tafsir sufi nadzari seorang sufi berpendapat bahwa semua ayat al-Qur'an mempunyai makna-makna tertentu dan bukan makna lain yang di balik ayat. Adapun dalam tafsir sufi isyari asumsi dasarnya bahwa ayat-ayat al-Qur'an mempunyai makna lain yang ada di balik makna lahir. Dengan perkataan lain bahwa al-Qur'an terdiri dari makna zahir dan batin.

\section{Paradigma Tafsir Sufistik}

Paradigma tafsir sufistik di sini dimaksudkan sebagai kerangka dasar, acuan,pijakan terhadap tafsir yang bercorak tasawuf ; berupa argumen yang dibangun (asumsi dasar) dan signifikansi tafsir ini. Penelusuran paradigma tafsir sufistik akan menunjukan posisi metodologis tafsir ini dari totalitas tafsir dengan menggunakan paradigma yang berbeda.

Sekedar review terhadap basis referensi (mashadir al-tafsir), di beberapa literatur metodologi tafsir Alquran disebutkan tentang sumber tafsir yang terbagi ke dalam tiga bagian; sumber informatif (المائور)), sumber nalar (المعقول) dan sumber intuitif (الإشارى ). Terma "informatif", "nalar" dan "intuitif" di satu sisi dianggap sebagai referensi, rujukan atau sumber. Di sisi lain dianggap sebagai pilihan dalam upaya "menafsir". Seorang mufasir mau menggunakan sumber informatif (المأثور), nalar ( المعقول) atau intuitf (الإشارى). Dalam konteks "upaya menafsir", terma informatif (المارثانثر ), nalar ( المعقول) atau intuitf (الإشارى) kemudian disebut dengan paradigma tafsir.

Paradigma informatif (المائور) berangkat dari asumsi dasar bahwa ketika seseorang hendak menafsirkan Alquran maka harus merujuk kepada informasi-informasi dari Nabi Muhammad saw., sahabat dan tabi'in ${ }^{14}$. Keniscayaan ini karena Nabi Muhammad saw., adalah sosok yang paling mengerti tentang Al Quran dan sekaligus maknamaknanya. Sementara para sahabat adalah murid-murid Nabi saw., dan para tabi'in adalah murid-murid para sahabat. Dengan kata lain, "memaknai", "menafsir" Alquran harus merujuk kepada orang-orang yang mengerti benar tentang seluk beluk Alquran sekaligus makna-maknanya, dalam hal ini adalah Nabi, sahabat dan tabi' in.

Paradigma nalar (المعقول) dalam menafsirkan Alquran adalah cara pandang bahwa upaya menafsir yang paling baik adalah dengan menggunakan nalar. Semua aktivitas menafsir adalah kerja akal atau melibatkan akal termasuk upaya merujuk kepada penafsiran $\mathrm{Nabi}$, sahabat dan atau tabi' in mesti melibatkan akal untuk memilah, mem-validasi informasi dan seterusnya. bagi para penganut paradigma nalar, sumber informatif (المأثور) tidak representatif baik dari keterwakilan ayat-ayat tertafsir, bahwa realitasnya ada sejumlah ayat yang tidak ditemukan informasinya dari Nabi, sahabat atau tabi'in karena mungkin informasinya tidak sampai atau memang Nabi, sahabat atau tabi' in tidak menafsirkannya.

Giliran tafsir sufi dengan bangunan paradigmatiknya; baik posisi tafsir sufi, asumsi dasar maupun kepentingannya. Sebagaimana telah disebutkan tentang paradigma informatif dan nalar, paradigma tafsir sufi masuk pada kategori ketiga (tafsir isyariy). Kategori ini berawal dari asumsi bahwa Alquran, dari aspek pemaknaannya terbagi kepada dua bagian besar; struktur makna dzahir dan struktur makna bathin. Makna dzahir Alquran menjadi wilayah "tafsir" dan makna bathin menjadi wilayah kerja takwil (التأويل). Takwil adalah cara kerja yang digunakan oleh kaum sufi dalam menafsirkan Alquran. Meskipun, penggunaan takwil tidak mutlak otoritas kaum sufi, karena para ahli tafsir dengan corak teologis (العقائدى) juga mengunakan takwil sebagai alat memaknai Alquran. Demikian juga corak-corak lain seperti corak filsafat, sains terkadang menggunakan takwil.

\footnotetext{
${ }^{14}$ Sulaiman al-Thayyar, Fushul fi Ushul al-Tafsir, Dar Ibn al-Jauzi li Nasyr wa al-Tauji' cet III, 53
} 
Abdullah al-Darraz mengibaratkan Alqur'an seperti permata intan yang setiap sudutnya memancarkan cahaya berbeda. ${ }^{15}$ Pernyataan ini senada dengan apa yang dikatakan Quraish Shihab bahwa Alquran seperti mutiara yang jika dilihat dari berbagai sudutnya akan terlihat indah ${ }^{16}$. Menurut Abdullah al-Darraz, Alqur'an merupakan kitab suci yang memiliki kandungan isi (content) multi-perspektif (dzu wujuh). Dalam perkembangan tafsir Alqur'an ditemui suatu situasi dimana upaya penafsiran Alqur'an bersinggungan dengan tradisi tasawuf. Selanjutnya, hasil dari persinggungan tersebut melahirkan ittijah (orientasi, corak, kecenderungan, aliran, warna) penafsiran Alqur'an khas kaum sufi yang biasa dikenal dengan tafsir sufiy atau tafsir sufistik.

Historisitas kemunculan tasawuf dalam agama Islam menurut Ignaz Goldziher-seorang orientalis berkebangsaan German-bukan berasal dari ajaran Islam itu sendiri. menurut asumsi Ignaz Goldziher, tradisi sufism dalam Islam berlangsung secara bertahap. Pada mulanya gerakan tasawuf muncul sebagai sikap zuhud secara total dan menjauhi hiruk-pikuk kehidupan dunia ('uzlah). Selanjutnya, karena banyak bersinggungan dengan filsafat Yunani, banyak juga dipengaruh oleh pemikiran emanasi ${ }^{17}$ yang sangat populer di kalangan penganut neo-platonisme dan meningkat pada perasaan (emosi) yang naik ke atas dan berujung pada perasaan rindu $(h u b b)$ kepada Allah. Ignaz Goldziher juga beranggapan bahwa ajaran sufism tidak bersumber dari Alqur'an, sumber rujukan dari sufism adalah faham emanasi Neo-Platonisme. Munculnya tafsir-tafsir Alqur'an yang bercorak sufi

15 Abdullah Darraz, al-Naba' al-'Adzim (Kairo: Dar al-‘Urubah, 1996), 111

${ }^{16}$ Quraish Shihab, Membumikan Alquran

${ }^{17}$ Teori emanasi banyak dibicarakan juga oleh para filosof Muslim seperti Ibn Sina dan al-Farabi dengan sebutan nadzariyat al-Faidl.

${ }^{18}$ Ignaz Goldziher, Madhahib al-Tafsir al-Islamy, Terj. 'Abd al-Halim al-Najjar 1955 (Kairo: Maktabah al-Madbuli, Rabea Adsawea, 201 menurutnya, hanya merupakan upaya para kaum sufi untuk mencari legitimasi atas faham sufi yang dianutnya. Meskipun menurut Ignaz Goldziher proses pencarian pembenaran ini tidaklah mudah. ${ }^{18}$

Sejarah perkembangan tafsir Alqur'an yang bercorak tasawuf tidak lepas dari perkembangan aliran tasawuf itu sendiri. Munculnya tasawuf dilatar-belakangi oleh sekelompok umat Islam yang merasa belum puas mendekatkan diri kepada Allah melalui ritual lahiriah (syari'at, figh) seperti shaum, shalat dan menunaikan ibadah haji. Kaum sufi merasa ingin dekat dengan Allah melalui cara hidup menuju penyatuan dengan Allah dan membebaskan diri dari keterikatan absolut pada kehidupan materil (dunyawiyyah), sehingga tidak diperbudak oleh kesenangan yang bersifat duniawiah tersebut. ${ }^{19}$

Praktek hidup sederhana ini sesungguhnya telah dilakukan sejak generasi awal Islam, ${ }^{20}$ Rasulullah Muhammad saw. merupakan sosok yang pertama kali mencontohkan praktek hidup sederhana. Di kalangan sahabat juga banyak yang mempraktekan pola hidup sederhana (zuhud) menjauhkan diri dari hiruk pikuk keduniawian. Meskipun perilaku tasawuf telah ada sejak masa awal Islam sebagaimana yang dilakukan oleh Nabi dan para sahabat, namun secara ekspisit terma tasawuf belum dikenal ketika itu. Secara eksplisit terma tasawuf mulai muncul dalam dunia Islam pada paruh abad ke II H. ${ }^{21}$ Dimana pada masa ini, secara berangsurangsur kehidupan umat Islam telah mengalami pergeseran nilai sehingga orientasi kehidupan umat Islam semakin kabur. pada masa inilah ada umat Islam yang berupaya mempertahankan pola hidup

19 Leni Lestari, "Epistemologi Corak Tafsir Sufistika”, Syahadah, Vol 02, No, 1. (April 2014), 9.

${ }^{20}$ Husayn al-Dhahby,al-Tafsir wa al-Munfasirun, Vol II (t.t.p: Maktabah Mus\}'ab bin 'Amir alIslamiyah, 2004), 81

${ }^{21}$ al-Dhahby,al-Tafsir wa al-Munfasirun, 82 
sederhana yang dikenal dengan qaum sufiah. $^{22}$ Orang yang pertama kali secara disebut sebagai sufi pada periode ini berdasarkan informasi yang diperoleh Muhammad Husen al-Dzahabi adalah Abu Hashim al-Sufi. ${ }^{23}$

Perilaku zuhud yang dilakukan oleh sebagian umat Islam periode pertama dan kedua berlanjut hingga masa perintahanan daulat Abbasiyyah (abad IV H), ketika itu umat Islam mengalami kemakmuran dan kejayaan yang membahwa pada perilaku hidup bermewah-mewahan di kalangan papan atas dan menengah (pejabat). Pada masa ini perkembangan tasawuf tidak hanya pada aspek praksis saja, tetapi sudah mulai ditandai dengan penjelasan-penjelasan teoritis yang ini menjadi embrio munculnya disiplin ilmu tasawuf. Pada masa ini pula, mulai adanya persinggungan kuat antara tasawuf dengan filsafat dan kalam (theosofi), ${ }^{24}$ sehingga muncul aliran tasawuf nazari dan tasawuf amaly.

Sebagaimana telah dije;askan sebelumnya, bahwa aliran tasawuf nazari (tasawuf teoritis) didefinisikan dengan; "aliran tasawuf yang berupaya membangun faham-faham tasawuf-nya berdasarkan teoriteori dan doktrin-doktrin filsafat. Struktur teoritik ini juga dipakai aliran tasawuf nadzari dalam memahami Alqur'an. Para sufi mengkaji Alqur'an dengan kajian yang sejalan dengan teori mereka dan sejalan dengan doktrin yang mereka anut. Sementara aliran tasawuf amaly (praksis) adalah aliran tasawuf yang mempraktekan hidup zuhud dan tidak melandasi perilaku mereka dengan teori-teori filsafat sebagaimana pada aliran tasawuf nadzari. Aliran tasawuf praksis menafsirkan Alqur'an berbeda dari makna yang zahir berdasarkan isyarat atau petunjuk

22 Leni Lestari, "Epistemologi Corak Tafsir Sufistika", 9 82

${ }^{23}$ Husayn al-Dhahby,al-Tafsir wa al-Munfasirun, , 82 yang diterima para ahli sufi ('ala ghairi ma yadzharu minha bi muqtadla isyaratin). ${ }^{25}$ Dua aliran tasawuf ini yang kemudian memberikan warna tersendiri dalam penafsiran Alqur'an perspektif para sufi.

Dalam perspektif tafsir sufistik, dikenal adanya empat terma yaitu; aspek dzahir (objektive) atau literal, bathin (subjektive) atau metaforikal/esoterik, had (intersujective) atau legal-formal dan mathla' (interobjektive) atau testimonial ${ }^{26}$. Kategori literal (dzahir) merupakan makna yang difahami oleh kalangan orang-orang awam, sementara legal-formal ( $\mathrm{had}$ ) adalah makna yang terkrelasi dengan aspek hukum (fiqh). Kemudin metaforikal, esoterik (bathin), adalah makna alegori (kiasan) sementara testimonial (mathla') adalah berkorelasi dengan pemaknaan pada dimensi hakikat. Empat terma tersebut merujuk pada hadis Nabi saw. :

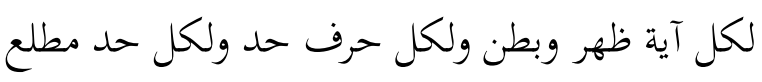

Penjelasan lain tentang empat terma tersebut yang senada dengan penjelasan sebelumnya adalah bahwa dzahir adalah teks ayat (tekstual, literal), adapun bathin adalah upaya pen-ta'wil-an ayat yang tekstual . Sementara had adalah aspek hukum seputar pahala dan siksa, sedangkan mathla' adalah aspek ma'rifat ${ }^{27}$. berdasarkan penjelasan tersebut maka fokus tafsir Isyari adalah pada dua hal; pemaknaan bathin dan mathla'. Sementara dua hal yang lainnya; yakni had masuk dalam wilayah fikih dan dzahir masuk dalam ranah pemaknaan untuk konsumsi orang awam secara umum.

Ibnu 'Abbas ra mengemukakan adanya isyarat pemaknaan batin terhadap al-Quran, Ia mengatakan sebagai berikut:

$$
\text { sesungguhnya al-Qur'an itu }
$$
memiliki cabang-cabang ilmu-

\footnotetext{
${ }^{25}$ Husen al-Dzahaby, al-Tafsir wa al-Munfasirun, , 82-92

26 Anwar Syarifudin, "Menimbang Otoritas Sufi dalam MenafsirkanAlqur'an", Studi Agama dan Masyarakat, Vol, 1. No, 2. 2004, Desember, 14

27 Abd al-'Adzim al-Zarqany, Manahil al-'Irfan, Vol II t.th, t.tp: Dar al-Fikr, 80
} 
ilmu, bagian-bagian yang dhahir dan yang batin. Keajaibannya tidak akan pernah habis dan sasarannya tak akan pernah dicapai secara tuntas, maka barang siapa yang masuk ke dalamnya dengan lemah lembut, niscaya selamat, tapi barang siapa yang memperlakukannya dengan kekerasan, pasti celaka. Didalamnya terdapat beritaberita, tamsil-tamsil, penjelasan mengenai yang halal dan yang haram, nasikh-mansukh, muhkammutasyabih, zahir dan batin. Dhahirnya adalah tilawah (bacaan) sedangkan bathinnya ialah ta'wil. Orang-orang yang berilmu sama menekuninya, sedangkan orang-orang yang bodoh mengesampingkannya ${ }^{28}$

Karena fokus tafsir sufistik adalah bathin dan mathla' maka jika dianalisis dengan menggunakan epistemologi nalar Arab yakni; bayani (empirisme), burhani (logisme) dan 'irfani (intuitisme), akan terlihat bahwa tafsir sufi masuk pada kategori epistemologi 'irfani (intuitisme). Nalar 'Irfani (intuitisme) adalah metode berfikir yang tidak didasarkan pada kasyf, tersingkapnya rahasia-rahasia yang dibukakan Allah. Karena nya, pengetahuan 'irfani (intuitisme) tidak dilandaskan pada proses analisa teks, tetapi lebih didasarkan pada pengolahan ruhaniyyah dan kesucian jiwa. Dari kesucian jiwa tersebut muncul pengetahuan yang diterima dari Tuhan secara langsung (isyariy) kemudian dibuat dalam bentuk konsep-konsep dan selanjutnya dikemukakan kepada orang lain secara logis (nadzariy).

Seorang tokoh orientalisme berkebangsaan Prancis bernama Massignon mengatakan bahwa sumber utama tafsir sufi

28 Abd al-Rahman al'Ak, Ushul al-Tafsir wa Qawa'iduhu, 208 adalah riyadlah (latihan penyucian jiwa) dan perjalanan spiritual. Karenanya, pengetahuan dalam perspektif tasawuf merupakan limpahan dari Allah (al-faid al-Ilahiyyah) yang bersifat transendental (ghaib), selanjutnya diturunkan kepada jiwa-jiwa manusia sesuai dengan tingkat dan kesiapan jiwa mereka masing-masing. ${ }^{29}$ Terma maqamat dan ahwal merupakan dua terma yang sangat populer bagi para pengkaji tasawuf, dimana jiwa manusia memiliki maqam-maqam (stations) yang lalui satu demi satu untuk mencapai level tertinggi. Dalam dunia tasawuf, manusia harus berupaya mensucikan diri untuk mencapai maqam (level) tertinggi agar selalu terhubung dengan tingkat tertinggi (al-mala' al-a'la). Jika seseorang telah mencapai tingkatan tertinggi ini, maka ia akan memperoleh pengetahuan hakikat (haq al-yaqin ) melampaui pengetahuan bersumber dari nalar/rasio ('ilm al-yaqin) dan pengetahuan indrawi ( $a$ 'in al-yaqin).

\section{Syarat-syarat Tafsir Sufistik}

Sebagaimana dikemukakan sebelumnya bahwa para pengkaji tafsir sufistik terbelah menjadi dua bagian; kelompok yang menolak tegas tafsir sufistik dan kelompok yang menganggap boleh dengan beberapa catatan. Artinya penafsiran sufistik tetap pada dua kutub yang berseberangan. Meskipun corak tafsir sufistik ini cukup kontroversial dan kurang mendapatkan perhatian, namun corak tafsir sufi telah diakui sebagai corak tafsir yang berdiri sendiri secara utuh dan memiliki bangunan epistemologi tafsir yang argumentatif.

29 Louis Massignon dan Muhammad 'Abd alRaziq, al-Tas \}awwuf 1984 (Beirut: Da>r al-Kitab alLubnani,), 55 
Mayoritas ulama, sebagaimana dikatakan oleh Abd al-Rahman al' $\mathrm{Ak}^{30}$ memberikan batasan-batasan berupa kesepakatan tentang adanya persyaratan bagi diterimanya tafsir ishari ${ }^{31}$. Syarat-syarat itu adalah sebagai berikut:

1. Tidak boleh bertentangan dengan makna dzahir dari susunan kalimat ayat-ayat al-Qur'an.

2. Tidak boleh meng-klaim bahwa itu satu-satunya penafsiran yang benar, bukan yang dzahir atau bukan penafsiran-penafsiran yang lain.

3. Tidak bertentangan dengan syara' dan akal.

4. Harus didukung oleh kesaksian syara' yang menguatkannya.

Syarat-syarat tersebut di atas merupakan rambu-rambu yang ditetapkan oleh para ulama supaya tidak terjadi penyimpangan dan "kesewenang-wenangan" menafsir dengan dalih isyarat-isyarat atau perenungan bathiniyyah.

\section{Pendekatan dan Corak Tafsir Sufistik}

Disiplin ilmu tasawuf dengan ruang lingkup sebagaimana yang telah diungkapkan dalam sejumlah literatur digunkan dalam upaya memaknai al-Quran. Seperti halnya disiplin-disiplin ilmu lain dapat digunakan dalam upaya menafsirkan al-Quran baik memaknaan kata, ayat maupun konsep-konsep tertentu. Titik tekan penafsiran al-Quran dengan menggunakan ilmu tasawuf akan terfokus pada dua hal; alAhwal wa al-Maqamat. Selanjutnya dikenal dengan istilah station-station tasawuf.

\footnotetext{
30 Abd al-Rahman al-'Ak, Ushul al-Tafsir wa Qawa'iduhu, , 208

${ }^{31}$ Basuni Faudah, 1977: 255

32 Frmulasi mawdlu'i telah dijelaskan oleh Abu
} Hay al-Farmawi dalam bukunya yang berjudul, al-
Metode yang digunakan dalam menafsirkan al-Quran dengan menggunakan pendekatan tasawuf adalah metode tematik (الموضوعى). Misalnya, seorang mufasir akan menafsirkan ayat-ayat mahabbah (المحتبّة) dalam al-Quran maka cara yang ditempuh besarannya adalah sebagai berikut:

1. Menentukan judul atau tema. Misal; Mahabbah dalam al-Quran (Pendekatan Sufistik).

2. Mengumpulkan ayat-ayat tentang mahabbah merujuk kepada kata kuncinya yakni kata mahabbah dengan berbagai derivasinya (tashrif).

3. Menuturkan munasabah (korelasi antar ayat atau surat) dan asbab alnuzul (sebab-sebab yang menyertai turunnya ayat)

4. Membuat kategori-kategori sistematis dari ayat-ayat yang telah dikumpulkan dimulai dengan pengertian mahabbah, pelaku, obyek dan aktivitas-aktivitas yang harus dilakukan dalam upaya mahabbah, dan seterusnya.

5. Merujuk kepada pendapat para tokoh tasawuf mengenai tema yang tengah ditafsirkan dengan menampilkan argumen yang dibangun (jika tafsir sufi nadzariy)

6. Membuat simpulan.

Selebihnya adalah mengikuti sistematika atau langkah-langkah tafsir tematik sebagaimana yang telah dibuat formulasinya oleh para pakar tafsir ${ }^{32}$

Cara kerja spesifik pendekatan sufistik adalah dengan menggunakan takwil (التأويل) sebagai lawan dari tafsir. Jika "tafsir" wilayah kerjanya pada pemaknaan kata, ayat atau surat dengan redaksi yang jelas (محكم)

Bidayah fi Tafsir al-Mawdlu'i, 1977, Kairo Mesir. Di Indonesia, seorang pakar tafsir telah menyebutkan hal yang sama, yakni Quraish Shihab dalam bukunya Membumikan al-Quran. 
maka "takwil" pada redaksi yang samarsamar atau tidak jelas.

Istilah takwil ini sesungguhnya mengalami pergeseran makna dalam rentang sejarah. Kata takwil awalnya digunakan untuk maksud tafsir, bahkan istilah tafsir sendiri tidak populer pada generasi awal. Contoh kasus adalah doa Rasulullah Muhammad saw kepada Ibn Abbas; اللهم فقهه (Ya Allah fahamkan lah فى الدين و علمه التأويل Ibn Abbas tentang agama dan ajarkan kepadanya takwil). Kata takwil yang dinyatakan Rasulullah tersebut merujuk kepada makna tafsir. Literatur tafsir pada masa klasik banyak yang diberi judul takwil untuk maksud tafsir, seperti karya Imam Thabari, "Jami al-Bayan li takwili Ayi alQuran”, karya Imam al-Khazin, Lubab alTakwil fi Ma'alim al-Tanzil, Imam Ibn Taimiyyah, Mahasin al-Takwil, dan karyakarya lainnya.

Pendekatan tafsir sufistik berarti menafsirkan Alquran dengan menggunakan tasawuf sebagai ilmu bantu. Ini sama saja dengan pendekatan sosial, pendekatan filsafat, pendekatan teologi, pendekatan sains dan seterusnya dimana disiplin ilmu yang disebutkan sebagai ilmu yang membantu mendekati Alquran. Sementara terma corak tafsir adalah penilaian seseorang ketika melakukan pembacaan tafsir terhadap tafsir tertentu. Jika seseorang membaca teks tafsir, di dalamnya banyak memaknai Alquran dengan terma-terma tasawuf maka disebut corak sufistik. Dengan kata lain, corak tafsir adalah penilaian pembaca terhadap kecenderungan, orientasi atau warna tafsir dengan penisbahan kepada dominasi disiplin ilmu tertentu, seperti halnya corak sufistik.

\section{Karya-karya Tafsir dan Contoh Penafsiran Sufistik}

a. Literatur tafsir dengan corak sufistik cukup banyak, diantaranya adalah:

1. Haqaiq al-Tafsir karya Imam alSulami

2. Lathaif al-Isyarah karya Imam alQusyairi
3. Tafsir al-Jilani karya Syekh Abdul Qadir al-Jailani

4. Gharaib al-Quran wa Raghaib alFurqan karya Imam al-Nisaburi

5. Tafsir Ibn 'Arabi karya Ibn Arabi

6. Tafsir Jawahir al-Quran karya Imam al-Ghazali

7. Al-Tafsir al-Jili karya Abu Yaghrab

8. Tafsir Al-Qur'an Al-Azhim, karya Imam At-Tutsuri

9. Arais Al-Bayan fi Haqa'iq Al-Qur'an, karya Imam As-Syirazi

b. Contoh Penafsiran Sufi Isyariy dan nadzariy

1). Contoh Penafsiran sufi Isyariy

Sebagaimana telah diulas sepintas tentang kasus penafsiran Alquran kaumsufi alGhazali menafsirkan potongan ayat

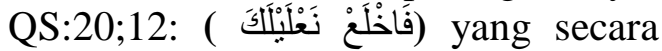
zahir "tinggalkanlah (Wahai Musa) kedua sandalmu". Menurut al-Ghazali makna batin dari ayat ini adalah "Tanggalkan (Hai Musa) kedua alammu, baik alam dunia mupun akhirat. Yakni, janganlah engkau memikirkan keuntungan duniawi dan jangan pula mencari pahala ukhrawi, tapi carilah ridla dan hub Allah”.

\section{2). Contoh Penafsiran sufi Nadzariy}

Muhammad Husen al-Dzahabi memberikan contoh penafsiran sufi nadhariy yang dipengaruhi ilmu filasafat yakni penafsiran yang dilakukan oleh Ibn al'Arabi terhadap firman Allah ayat 57 Surat Maryam : وَرَفَعْنَهُ مَكَانًا عَلِيًّا Artinya: "Dan Kami telah mengangkatnya ke martabat [tingkat] yang tinggi". Menurut Imam al-Dzahabi penafsiran Ibn'Arabi tersebut sangat dipengaruhi oleh pemikiran filasafat yaitu dengan menafsirkan lafadz makanan 'aliyyan dengan makna "antariksa" (alam bintang). 
Kaum Bathiniyah, ${ }^{33}$. mereka mengembangkan tafsir bathiniy yang disesuaikan dengan ajaran-ajaran mereka sendiri. Misalnya saja ketika menafsirkan surat al-Hijr ayat 99 yang berbunyi:

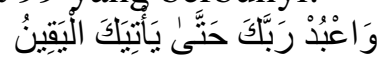

Mayoritas ulama tafsir menafsirkan ayat tersebut dengan:"sembahlah Tuhanmu sampai ajal tiba". Namun qaum Bathiniyah mengembangkan penafsiran yang berbeda serta mengabaikan makna dzahirnya. Menurut kaum Bathiniyah makna ayat itu adalah "barangsiapa yang telah mengerti makna ibadah, maka pada saat yang sama gugurlah kewajibankewajiban baginya"34. Dengan kata lain, ibadah itu memiliki rentang yang batas akhirnya adalah keyakinan. Jika sudah yakin maka selesai ibadahnya.

\section{Kelebihan dan Kekurangan Tafsir Sufistik}

Karya yang dinilai akan ditemukan dua kemungkinan - meski tidak selalu demikian-memiliki kelebihan dan kekurangan, tidak terkecuali karya tafsir dengan corak sufistik.

a. Kelebihan Tafsir Sufistik

1). Mengisi ruang pemaknaan pada wilayah esoterik atau dimensi bathin-nya

2). Sangat tepat untuk rujukan orang-orang yang berkehendak meningkatkan martabat spiritual

b. Kekurangan Tafsir Sufistik

1). Difahami hanya oleh kalangan tertentu

2). Karya-karya tafsir bercorak sufistik mayoritas menggunakan metode tahlily dengan teknik penafsiran mengikuti runtut mushaf Utsmani. Dengan teknik ini akan sulit menangkap makna Alquran secara tematis, karenanya penafsiran sufistik — sebagaimana yang menggunakan metode tahlily dengan corak lain-bersifat parsial.
3). Tidak ada tolok ukur yang jelas validitas tafsir dengan corak ini, karena penafsirannya diambil dari isyaratisyarat yang samar (isyarah khafiyyah).

\section{PENUTUP}

Tafsir sufi isyariy adalah salah satu corak tafsir yang dalam memberikan pemaknaan terhadap ayat-ayat al-Qur'an menggunakan perangkat takwil, aspek-aspek esoteric dan isyarat-isyarat yang terkandung dalam teks ayat-ayat al-Qur'an. Terlepas dari kontroversi yang terjadi dalam mengomentari corak tafsir ini, yang jelas tafsir sufi isyariy adalah sebuah upaya "memaknai" dan tentunya memberi kontribusi dalam memperkaya khazanah litelatur-literatur tafsir dan upaya mencerahkan umat, memperluas pemahaman tentang makna al-Qur'an atau paling tidak, pembacaan terhadap tafsir sufistik dianggap sebagai "wisata intelektual".

Sejalan dengan kepentingan mencerahkan umat dengan merujuk kepada kepentingan Alquran sebagai petunjuk sepanjang zaman, maka tidak menutup kemungkinan ada upaya-upaya yang inovatif pengembangkan tafsir sufi isyariy dan tafsir sufi nadzariy untuk kepentingan hidayah pada masa sekarang dan masa yang akan datang dengan tetap mengindahkan batasan-batasan atau syarat yang telah ditetapkan oleh para ulama.

Tafsir Alquran bersifat relatif dan yang absolut adalah Alquran sebagai Kalam Allah. Alquran sebagai teks tertafsir, karena produk pemikiran $\left(\mathrm{ra}^{\prime} \mathrm{yu}\right)$ dan isyarat-isyarat (isyariy) yang dimungkinkan berbeda satu sama lain, termasuk penukilan-penukilan dari Nabi, sahabat dan tabi'in yang pada dataran praksisnya adalah kerja akal dalam memilih dan memilah informasi plus menafsir informasi-informasi tersebut, tetap saja relatif.

\footnotetext{
${ }^{34}$ Basuni Faudah, 1977: 217
} 


\section{E. DAFTAR PUSTAKA}

Asimain, al-Fikr al-Shufiy fi Dlau al-Quran wa al-Sunnah,

Abd al-Rahman al-'Ak, Ushul al-Tafsir wa Qawa'iduhu, 1986. Dar al-Nafais Damaskus Syiria cet. Ke III

Al-Qusyairiy, al-Risalah al-Qusyairiyyah

Abu Nu'aim, Hilyah al-Auliyâ'

Abu Hay al-Farmawi dalam bukunya yang berjudul, al-Bidayah fi Tafsir alMawdlu'i, 1977, Kairo Mesir.

Abdullah Darraz, al-Naba' al-'Adzim (Kairo: Dar al-'Urubah, 1996)

Abd al-'Adzim al-Zarqany, Manahil al'Irfan, Vol II t.th, t.tp: Dar al-Fikr.

Ali al-Shabuni, Muhammad., Rawa'i alBayan, 1999

Anwar Syarifudin, "Menimbang Otoritas Sufi dalam MenafsirkanAlqur'an", Studi Agama dan Masyarakat, Vol, 1. No, 2. 2004, Desember.

Faudah, Mahmud Basuni Faudah., Tafsir-
Tafsir Alquran; Perkenalan dengan Metodologi Tafsir1987. Cet I Pustaka Bandung.

Husayn al-Dhahby,al-Tafsir wa alMunfasirun, Vol II (t.t.p: Maktabah Mus\}' ab bin 'Amir al-Islamiyah, 2004).

Ignaz Goldziher, Madhahib al-Tafsir alIslamy, Terj. 'Abd al-Halim al-Najjar 1955 (Kairo: Maktabah al-Madbuli, Rabea Adawea

Louis Massignon dan Muhammad 'Abd alRaziq, al-Tas \}awwuf 1984 (Beirut: Dar al-Kitab al-Lubnani)

Quraish Shihab, Membumikan Alquran; Fungsi dan Peran Wahyu dalam Kehidupan Masyarakat, 1996. Penerbit Mizan Bandung.

Sulaiman al-Thayyar, Fushul fi Ushul alTafsir, Dar Ibn al-Jauzi li Nasyr wa alTauji' cet II. 